\title{
Response of rats to a moderate intake of soyabean lectin*
}

\author{
J. Czerwiński ${ }^{1,2}$, H. Leontowicz ${ }^{1}$, M. Leontowicz ${ }^{1}$ and M.A. Gralak ${ }^{1}$ \\ ${ }^{1}$ Warsaw Agricultural University, Faculty of Veterinary Medicine, \\ Department of Physiological Sciences \\ Nowoursynowska 159, 02-776 Warszawa, Poland \\ ${ }^{2}$ The Kielanowski Institute of Animal Physiology and Nutrition, Polish Academy of Sciences \\ 05-110 Jabtonna, Poland
}

\begin{abstract}
Soyabean lectin preparation (SBA) containing about $50 \%$ active lectin was given in a dose of $0.73 \mathrm{mg} / \mathrm{g}$ diet to 10 male rats for 31 days, while control group obtained the same diet without SBA. The performance and $\mathrm{N}$ balance were measured, then the rats were killed and activity of enzymes was measured in pancreas and plasma. The SBA supplementation had no significant effect on the diet intake, body weight gain, dry matter, and protein digestibility. However, it depressed $\mathrm{N}$ retention by an increase at $\mathrm{N}$ excretion in urine. The activity of amylase in plasma, the pancreas weight and trypsin activity in pancreas did not significantly differ between groups.
\end{abstract}

KEY WORDS: soyabean lectin, nitrogen balance, amylase activity, trypsin activity, rats

\section{INTRODUCTION}

Plant lectins are carbohydrate-binding proteins, which bind to glycolipids and glycoproteins of the brush border membrane, and can affect both morphology and functions of digestive tract, and nitrogen metabolism. Effects of lectins depend on their origin, dose and duration of feeding (Rådberg et al., 2001; Li et al., 2003b). Animals are exposed mainly to soyabean lectins which are present in soya products in amounts depending on heat treatment and ranging from $0.05 \mathrm{mg} / \mathrm{g}$ in normally toasted soya meal to $10-20 \mathrm{mg} / \mathrm{g}$ in raw seeds (Schulze et al., 1995). The aim of the study was to estimate the effect of moderate dose of soyabean lectins (SBA) on performance, nitrogen balance and selected blood and pancreas parameters in growing rats.

\footnotetext{
* Supported by the State Committee for Scientific Research, Grant No. 5 P06E 03708

${ }^{2}$ Corresponding author: e-mail: j.czerwinski@ifzz.pan.pl
} 


\section{MATERIAL AND METHODS}

Lectins (SBA) were extracted from raw soyabean seeds according to Santiago et al. (1993). Lectin activity was estimated by the agglutination test with human $0, \mathrm{~A}, \mathrm{~B}$ and $\mathrm{AB}$ red blood cells and compared to Sigma standard (Liener, 1989). Twenty male Wistar rats weighing 130-140 g were allocated into 2 groups, and fed ad libitum standard diet containing $15 \mathrm{~g}$ crude protein/ $\mathrm{kg}$ (control group - C) or the same diet with SBA added to daily portion in amount $15 \mathrm{mg} /$ day/rat. Feed intake and body weight was measured during 31 days, in the third week faeces and urine were collected for 5 days. At the end of the experiment rats were killed, blood samples were taken from the heart, and pancreas was excised. The DM and $\mathrm{N}$ content in diets and excreta was determined by standard methods, the level of protein, urea, glucose and $\alpha$ amylase activity in plasma and trypsin activity in pancreas were determined as in Leontowicz et al. (2004) study.

The results were evaluated by ANOVA and the Student test.

\section{RESULTS}

The SBA preparation agglutinated human $\mathrm{RBC}$, with the highest affinity to the $\mathrm{AB}$ group, showed about half of the activity of pure soyabean lectin (Table 1). As the average daily feed intake in SBA group was $20.1 \mathrm{~g}$ (Table 2), the calculated active lectin level in SBA diet averaged $0.37 \mathrm{mg} / \mathrm{g}$ and had no significant effect on feed intake, BWG, feed and protein efficiency ratio, the excretion of $\mathrm{N}$ in faeces as well as the coefficient of DM and protein digestibility in comparison with the control group (Table 2). However the excretion of $\mathrm{N}$ in urine increased $(\mathrm{P}<0.05)$ and $\mathrm{N}$ retention was lower in $\mathrm{SBA}$, than in control group (Table 2). The SBA extract had no significant influence on the concentration of protein, urea and glucose in plasma and on weight and trypsin activity in pancreas (Table 3 ).

Table 1. Haemagglutination titre of human red blood cells by pure soyabean lectin and SBA extract

\begin{tabular}{lcccc}
\hline \multirow{2}{*}{ Soyabean agglutinin } & \multicolumn{4}{c}{ Red blood cells } \\
\cline { 2 - 5 } & $\mathrm{A}$ & $\mathrm{B}$ & $\mathrm{AB}$ & 0 \\
\hline Pure lectin (Sigma) & 0.62 & 1.25 & 0.31 & 0.62 \\
SBA extract & 1.25 & 2.50 & 0.62 & 1.25 \\
\hline
\end{tabular}

the result are the lowest concentration of soyabean lectin, $\mu \mathrm{g} / \mathrm{ml}$, which showed agglutination 
Table 2. The influence of SBA extract on performance (31 days) and $\mathrm{N}$ balance in rats

\begin{tabular}{lccc}
\hline \multirow{2}{*}{ Item } & \multicolumn{2}{c}{ Group } & \multirow{2}{*}{ Pooled SEM } \\
\cline { 2 - 3 } & control & SBA & \\
\cline { 2 - 3 } Performance, 31 days & & & 0.5 \\
feed intake, g/day & 21.1 & 20.1 & 0.11 \\
body weight gain, g/day & 5.36 & 5.08 & 0.06 \\
feed efficiency ratio, g feed/g BWG & 3.94 & 3.96 & 0.01 \\
Protein efficiency ratio & 0.81 & 0.82 & \\
N-balance, 5 days & & & 0.6 \\
DM intake, g/day & $22.2^{\mathrm{a}}$ & $21.8^{\mathrm{a}}$ & 0.01 \\
N intake, g/day & $0.73^{\mathrm{a}}$ & $0.72^{\mathrm{a}}$ & 0.01 \\
N in faeces, g/day & $0.21^{\mathrm{a}}$ & $0.20^{\mathrm{a}}$ & 0.012 \\
N in urine, g/day & $0.098^{\mathrm{a}}$ & $0.140^{\mathrm{b}}$ & 0.01 \\
N retention, g/day & $0.42^{\mathrm{b}}$ & $0.38^{\mathrm{a}}$ & 1.0 \\
DM digestibility, \% & $74.2^{\mathrm{a}}$ & $76.4^{\mathrm{a}}$ & 1.5 \\
Protein digestibility, \% & $71.5^{\mathrm{a}}$ & $72.6^{\mathrm{a}}$ & \\
a,b- values within rows with no common superscripts were significantly different at $\mathrm{P} \leq 0.05$
\end{tabular}

Table 3. The influence of SBA extract on some plasma and pancreas parameters in rats

\begin{tabular}{lccc}
\hline \multirow{2}{*}{ Parameter } & \multicolumn{2}{c}{ Group } & \multirow{2}{*}{ Pooled SEM } \\
\cline { 2 - 3 } & control & SBA & \\
Plasma & & & 67 \\
amylase activity, IU/1 & 677 & 752 & 2.4 \\
protein, g/1 & 59.0 & 55.6 & 0.3 \\
urea, mmol/1 & 7.4 & 7.1 & 0.8 \\
glucose, mmol/1 & 3.5 & 5.0 & \\
& & & \\
Pancreas & & & 0.01 \\
weight of pancreas, \% BW & 0.30 & 0.29 & 0.019 \\
trypsin activity, U/pancreas & 0.373 & 0.363 & 2.54 \\
trypsin activity, U/g protein & 49.75 & 39.85 & 0.70 \\
protein, mg/pancreas & 7.56 & 9.11 &
\end{tabular}

all differences between means were not significant

\section{DISCUSSION}

The level of soyabean lectin used in the present study averaged $0.37 \mathrm{mg} / \mathrm{g}$ diet, and was comparable to the level found in the diet containing about $10 \%$ of inadequately processed soya meal according to Schulze et al. (1995). Anti-nutritional effects of soyabean agglutinin are dose-dependent. Li et al. $(2003 \mathrm{a}, \mathrm{b})$ showed, that doses from 0.1 to $1.2 \mathrm{mg} \mathrm{lectin} / \mathrm{g}$ diet had no significant influence on rats performance, what agree with results of Liener (1994) and with the present study. Our results as well as results at Li et al. $(2003 \mathrm{a}, \mathrm{b})$ indicate, that moderate intake of lectins can negatively affect nitrogen retention. According to Grant et al. (1997) and Li et al. 
(2003b) the effect is more pronounced as lectin levels increases, and at fairly high intake also affects the protein digestibility, indicating for a damage of the digestive tract. Contrary to Li et al. (2003a) in our study no pancreatic enlargement has been observed. It may be concluded, that long-term feeding the moderate amounts of SBA lectin may negatively influence protein metabolism.

\section{REFERENCES}

Grant G., Buchan W.C., Bardocz S., Pusztai A., 1997. Nitrogen balance and body composition of rats fed soyabean proteins, lectin or trypsin inhibitors. In: S. Bardocz, M. Muzquiz, A. Pusztai (Editors). COST 98. Effects of Antinurients on the Nutritional Value of Legume Diets. Eur. Commun. 4, 103-108

Leontowicz H., Leontowicz M., Czerwiński J., Kostyra H., Krzemiński R., 2004. Influence of lectins isolated from soyabean seeds and evening primrose seeds and cake on rat metabolism. In: 4th International Workshop on Antinutritional Factors in Legume Seeds and Oilseeds. Toledo (Spain). EAAP Publication No. 110, pp. 115-119

Li Z., Li D., Qiao S., 2003a. Effects of soybean agglutinin on nitrogen metabolism and on characteristics of intestinal tissues and pancreas in rats. Arch. Tierernähr. 57, 369-380

Li Z., Li D., Qiao S., Zhu X., Huang C., 2003b. Anti-nutritional effects of a moderate dose of soybean agglutinin in the rat. Arch. Tierernähr. 57, 267-277

Liener I.E., 1989. Control of antinutritional and toxic factors in oil seeds and legumes. In: W.E.W. Lusas, D.R. Erikson, W. Nip (Editors). Food Uses of Whole Oil and Protein Seeds. Amer. Oil Chem. Soc., pp. 344-371

Liener I.E., 1994. Implication of antinutritional components in soybean foods. Crit. Rev. Food Sci. Nutr. 34, 31-67

Rådberg K., Biernat M., Linderoth A., Zabielski R., Pierzynowski S.G., Weström B.R., 2001. Enteral exposure to crude red kidney bean lectin induces maturation of the gut in suckling pigs. J. Anim. Sci. 79, 2669-2678

Santiago J.G., Levy-Benshimol A., Carmona A., 1993. Effect of Phaseolus vulgaris on glucose absorption, transport and metabolism in rat everted intestinal sacs. J. Nutr. Biochem. 4, 426430

Schulze H., Saini H.S., Huisman J., Hessing M., Berg W.V.D., Verstegen W.A., 1995. Increased nitrogen secretion by inclusion of soya lectin in the diets of pigs. J. Sci. Food Agr. 69, 501-510

\section{STRESZCZENIE}

\section{Reakcja szczurów na umiarkowane spożycie lektyny soi}

Preparat lektynowy z soi (SBA), wykazujący 50\% aktywność czystej lektyny, podawano w ilości $0,7 \mathrm{mg} / \mathrm{g}$ diety 10 szczurom przez 31 dni doświadczenia. Grupę kontrolną karmiono taką samą dietą bez dodatku SBA. Określono parametry wzrostowe i bilans N, następnie zwierzęta uśmiercono oraz zmierzono aktywność enzymów w trzustce i osoczu. Dodatek SBA nie wpływał istotnie na spożycie paszy, przyrosty masy ciała zwierząt oraz strawność suchej masy i białka, powodował jednak istotne zwiększenie wydalania N z moczem oraz spadek retencji N. Aktywność amylazy w osoczu, masa trzustki i aktywność trypsyny w trzustce nie różniły się istotnie między grupami. 